\title{
THE ROLE OF LITTLE GIRLS IN THE LIFE AND LITERATURE OF NATHANIEL HAWTHORNE AND LEWIS CARROLL
}

\author{
Julieta Ojeda Alba \\ Universidad de La Rioja
}

\begin{abstract}
It is of course widely known that Lewis Carroll's remarkable attraction to prepubescent little girls in general, and to Alice Lidell in particular, compelled him to write and publish in 1865 Alice's Adventures in Wonderland, the first of his 'Alice books' which procured him a place among the pioneers of children's books. However, it is fair to remark that he was by no means the first writer to feel this sway and reflect it in his literary works. By the time Carroll was born in 1832, in a much less conspicuous way, the American Nathaniel Hawthorne had already felt the strong influence of some "beautiful little girls" who made the creation of most of his children characters possible. Our aim in this article is to demonstrate that, although Hawthorne's penchant may have not been as noticeable as Carroll's, it was still perceptible enough to raise some suspicions that lead us now to a better understanding of his fiction.
\end{abstract}

RESUMEN: El hecho de que fue la notable atracción de Lewis Carroll por niñas en la prepubertad, especialmente por Alice Lidell, lo que le llevó a componer libros como Las Aventuras de Alicia en el país de las maravillas es hoy generalmente aceptado; sin duda este primer libro de la serie le procuró un lugar entre los pioneros de los autores infantiles. Sin embargo Lewis no fue el primer autor que sintió esta atracción por las niñas y que la reflejó en su obra literaria. Para 1832, año del nacimiento de Lewis, un americano, Nathaniel Hawthorne ya había sido influido en su trabajo por algunas de esas niñas o como él las llamaba, "beautiful girls", que hicieron posible la creación de sus más característicos personajes infantiles. Nuestra intención en este breve ensayo es demostrar que aunque la inclinación de Hawthorne no fue advertida en su tiempo fue bastante evidente como para levantar sospechas que nos llevan a un mejor entendimiento de su narrativa.

Childhood has traditionally been a symbol of innocence and purity in literature; due to their need of guidance and protection, children in fiction, while eliciting feelings of tenderness, have also been the object of compassion. However, for many years they did not occupy a central place in poetry or fiction. In England, they first appeared in roles of any significance in late eighteenth-century and early nineteenthcentury poetry. William Blake, recognising the essential ambiguity of man, saw children as the embodiment of innocence, but at the same time he detected in them the presence of evil. Childhood permeated William Wordsworth's poems and its 
innocence located little children nearer to truth and God. For this romantic poet loss of innocence was frequently associated with death; and the concept of an experienced child seemed shockingly contradictory.

Meanwhile in America, where the romantic trend took longer to arrive, early nineteenth-century literature portrayed more down-to-earth child characters who were often flawed, although trying to improve. Flaws drove children to commit errors, but these errors eventually proved to be the means of their redemption. By the late $1840 \mathrm{~s}$ big American cities were fraught with poverty-stricken children, and these began to appear in literature as vehicles of social protest. Some writers such as Sara Parton endeavoured to call attention to this situation by means of sentimentality. The economic expansion after the civil war caused the crowd of poor, destitute children to disappear from the streets of big cities and from literature, but sentimentalism about children remained; as the century advanced, fictional children became increasingly idealised. Throughout these fluctuations boys and girls equally held the roles of leading characters; however there is a collection of fictional female children with specific circumstances and it is on them that this paper focuses its discussion.

When reflecting on the topic of female children and their role in nineteenthcentury literature the names Lewis Carroll and his Alice's Adventures in Wonderland readily come to mind. It is no secret that Reverend Charles Dodgson, of Christ Church, Oxford, was uncommonly attracted to little girls in general, and to Alice Lidell, the daughter of Dean Henry George Lidell, in particular. Neither is it news that it was precisely this intense and possibly pathological attraction to pre-pubescent females that induced him to write, under the pseudonym of Lewis Carroll, the "Alice" books which are among the most delightful pieces of British literature. Alice Lidell was the muse and driving force that made their creation possible. At a summer picnic outing on July 4, 1862 Dodgson had entertained her with the story about a girl who fell down a rabbit hole; and it was later, at her request and with no initial plans for publication, that he first wrote down the story which was to become a classic.

However, Carroll was not the first writer of his century to betray such a fascination with female children. Across the ocean, in America, little girls were becoming important in literature. In particular a sensitive New Englander, Nathaniel Hawthorne, had already produced by the time Carroll was born, some literature of similar motivation. This short paper aims at demonstrating that, although Lewis' penchant was by far the most conspicuous of his time, the tendency was tangible enough in others to raise some suspicions that now lead us to a closer analysis and to a better understanding of their fiction. The Englishman's infatuation with young girls was a much more overt matter than that of his American counterparts. Dodgson, to his good fortune, found a valid excuse to be in frequent association with them and, moreover, to be explicit about his exchanges. Because he was a well known and enthusiastic amateur photographer he was allowed to photograph little girls, receive them for dinner at his rooms in Christ Church, and correspond with them at all times. 
These oddities of Dodgson seem to have been widely noticed and commented upon, but suspicions never were solid enough to endanger his status as an Oxford don. His favourite activity, surprisingly enough, continued unquestioned for years. In fact, when perusing some of his letters, the twentieth century reader most probably wonders how he managed to pass unsuspected of any immoral schemes. On one occasion, for instance, he wrote to Anthony Lawson Mayhew, father of Ruth, Ethel, and Janet, three young girls whom he wanted to photograph, a letter which included this astounding passage:

First, the permission to go as far as bathing-drawers is very charming, as I presume it includes Ethel as well as Janet... though I hardly dare hope that it includes Ruth. I can make some charming groups of Ethel and Janet in bathingdrawers, though I cannot exaggerate how much better they would look without. Also the bathing-drawers would enable me to do a full front view of Ethel, which of course could not be done without them: but why should you object to my doing a back view of her without them? It would be a perfectly presentable picture, and far more artistic than with them. As to Janet, at her age they are surely unnecessary, whatever view were taken. ${ }^{1}$

The fragment is shocking indeed, but it is still more shocking that the girls' family should have granted permission, even with the condition that Mrs. Mayhew accompany them for the session. Dodgson, nevertheless, did not agree with the condition. He reacted as if he had received an insulting offence and wrote back declining the offer altogether because, he said, "I should have no pleasure in doing any such pictures, now that I know I am not thought fit for, only permitted, such privilege except on condition of being under chaperonage. I had rather do no more pictures of your children except in full dress" (Cohen 341). Was this the reaction of someone whose innocence had been deeply offended, or was it just plain guilt and disappointment at having lost a golden opportunity of being the only adult in the presence of naked young girls?

In the case of Hawthorne the fondness was far more private. For instance, the suggestion of some kind of rapport between this author and little girls took people within his inner circle by surprise. After the publication of "Little Annie's Ramble", his first story portraying a female child character, his schoolmate and intimate friend Horatio Bridge commented on the topic:

It must be that you had some particular child in your mind's eye, and perhaps did actually take the walk. How was it? Have you a smile that is more winning to children than other men's? I don't remember to have heard you say anything about your partiality for children. (J. Hawthorne 1: 151)

In most cases longings for the company of little girls are explained as an intense desire to retain ephemeral infancy. In the words of the narrator of Grandfather's Chair, 
"It grieved him [grandfather] to think that his little Alice, who was a flower bud fresh from paradise, must open her leaves to the rough breezes of the world, or even open them in any clime" (67). ${ }^{2}$ These words echo what Hawthorne said about his daughter Una when she was about to enter her teen years. He writes from England to his wife Sophia who was in Portugal with their two daughters: "I long unutterably to see her [Una], and cannot bear to think that she has been growing out of her childhood, all this time" (17: 465). ${ }^{3}$ Dodgson shares these same anxieties. He wrote to the father of Edith Jebb, one of his numerous little friends: "I should so much like to see you all again, though I can't help fearing that at last Edith has ceased to be a child, and that I shall find her with her hair done 'á la grown up'. Is it so? It will be a great shock to my feelings!" (Cohen 1: 216). Again this same aspiration to retain childhood, and this same vision of adulthood as a threat pervades J. M. Barrie's Peter Pan, an escapist story where an elfin boy who never grows up and a tiny fairy take the children of a family to a Never-Never land. The compulsive obsession to associate with female children was plausibly explained by Dodgson when he said that it was their "innocent unconsciousness" that appealed to him. Hawthorne also attributed his interest in immature females to their naive innocence. They were for him the only representatives of the men and women of the Golden Age of Eden, when "Evil had never yet existed" (7: 14). If there were more obscure cravings, both of them understandably chose to subdue them, and it goes without saying that their little models or friends were unmolested.

Though more private, Hawthorne's interest was as urging as Carroll's. What probably made the latter's case so conspicuous is that his passion (presumably aesthetic) was mainly focused on the bodies of young female children, as his obsessive desire to take nudes of them demonstrates. Meanwhile, Hawthorne's interest, though he was by no means blind to the grace and beauty of pre-adolescent female forms, focused on their spirit. This, paradoxically, rendered his fondness less blatant, though he had in fact gone one step further than his English counterpart. He, as well as his adult male characters, appears to have had an irresistible impulse to capture and imprison little girls' minds, a longing to posses and dominate their souls. Curiously enough the yearnings of men for the dominant possession of female children were portrayed even by female writers. In Martha Finley's Elsie Dinsmore Elsie's father tells the girl at one point: "You are mine... you belong to me; no other earthly creature has the least shadow of a right or title in you" (227). Carroll also saw little girls as possessions, and in his first letter to Mayhew he wrote: "Dear Sir, It

2. All parenthetical references to The Whole History of Grandfather's correspond to the 1851 Houghton \& Mifflin edition listed in the bibliography.

3. All works by Nathaniel Hawthorne, unless otherwise stated, correspond to The Centenary Edition of the Works of Nathaniel Hawthorne listed in the bibliography; volume number of this edition is included in the parenthetical references. 
dawned on me, after we parted in the road last night, that perhaps you are the owner of a certain Ruth Mayhew whom Mrs. Arnold and other friends have told me I ought to photograph" (Cohen 1: 218; my emphasis).

Dodgson's photographs might lead us to believe that his interest in little girls had some overtones of eroticism and Hawthorne's did not, but things are not clear. In spite of the cold personality attributed to Hawthorne, eroticism played an important part in his life and works. His keen awareness of female beauty and sexuality as shown in his notebooks is outstanding, and in his fiction some of his major characters such as Hester or Zenobia are testimony to this appreciation. Moreover, his eroticism was not exclusively related to adult men and women, over his fictional little girls there is frequently hovering the same almost imperceptible aura of sensuality we find in Dodgson's photographs. ${ }^{4}$ The difference lies perhaps in that Hawthorne was a more reserved man, and also in that he did not have to fulfil his eroticism by means of his relationship with little girls. He found gratification somewhere else. His matrimony has traditionally been considered as a model of connubial love, and their "blissful encounters", as he and his wife referred to sexual intercourse, were an essential ingredient of their relationship.

He seems to have had a perfect solution. It has been suspected, as Walter T. Herbert points out, that one of the main reasons why he fell in love and married Sophia Peabody was because everyone, including herself, considered her to be a child-woman. When Hawthorne met Sophia she had for twenty eight years practised a childlike dependency on her mother, who took care of her in preference to all her other children because of her frequent migraines. ${ }^{5}$ Indeed, according to her sister Elizabeth, Sophia "was an instance, if ever there was one in the world... of growing up innocent and forever improving" (qtd. in Pearson 270). Her own son Julian declared that "She was a child of frolicsome spirits" (J. Hawthorne 1: 47). The list of remarks supporting this idea is long. Apparently wanting to continue this role, Sophia sought to retain her childlike status after she gave birth to her daughter. Herbert, again, has called attention to the fact that she composed letters in the child's name, "articulating the unspoiled consciousness she sought to retain in herself by voicing its perfection in her baby" (1989: 49).

Importantly, all along Hawthorne happily endorsed Sophia's claims to an unmarriageable "childhood". He wrote to Elizabeth Peabody about Sophia: "She is a flower to be worn in no man's bosom, but was lent from Heaven to show the possibilities of the human soul" (qtd. in J. Hawthorne 1: 181). In spite of this

4. Hawthorne wrote in his notebooks: "Three little girls, from six to nine, were sitting on the stones in which the fountain is set, and paddling in the water. It was a pretty picture, and would have been prettier, if they had shown bare little legs, instead of pantalets" (8: 5).

5. Sophia Peabody was considered a semi-invalid because she had suffered strong headaches from early childhood. 
declaration he deemed himself fit to wear that "flower", possibly on account of his personal claims to an extended boyhood. In marrying Sophia, Hawthorne was simultaneously acquiring for himself a female "child" companion and thus confirming his own status as a boy. From the Old Manse he wrote a few days after their wedding had taken place: "My life, at this time, is more like that of a boy, externally, than it has been since I was really a boy" (Arvin 95). Believing in the blissfulness of returning to the status of childhood through marriage, he recommended to his friend Horatio Bridge that he marry because thus "[Bridge] would be a boy again" (Bridge 93). On the contrary Carroll had no childlike wife with whom he could indulge his fantasies, and he did not reflect them in his literature. His photographs served him well.

Even without a childlike wife Hawthorne's case would have never been as overt as Carroll's, for his emotions were always under control. Sophia wrote to Elizabeth Peabody that "Mr. Hawthorne's passions were under his feet" (qtd. in Pearson 275). There must have been a great deal of truth in her statement for, even before their marriage, he had thoroughly planned the children they were to procreate. Sophia once told her sister that he proposed "they should have but three children, and that there should be two and a half years between the first two, and five between the second and third" (qtd. in Pearson 276). This is exactly how things happened. Thus, taking into account the limited knowledge and means of birth control at the time, it must be concluded that Hawthorne managed quite well to maintain self-control in the face of sexual desire. ${ }^{6}$ Current literary criticism of this author shares the same view. John Updike, who has written abundant literary criticism on Hawthorne, besides parodying his Scarlet Letter in four novels, lately referred to him as "a cold fish".7

However, Hawthorne's reserve could not shroud his feelings for little girls completely; they were unusually strong. He was not simply interested in them, he even wanted at times to identify himself with them. He once wrote to his mother: "Why was I not a girl that I might have been pinned all my life to my Mother's apron" (15: 117). His feminine traits were soon detected by some. Emerson, for instance, commented that when talking to Hawthorne "You might fancy yourself talking to a girl, he is so gentle \& mild." were mostly away from Salem during Nathaniel's childhood it naturally happened that the boy spent his time almost entirely in the society of women, and he concludes: "That this situation had an effect on his character cannot be denied" (M. Hawthorne 10). This "undeniable" impact on his character had its counterpart in literature.

6. In nineteenth-century America the obsession of middle-class males with sexual self-mastery had obvious economic motives. Sylvester Graham and others designed programs of diet and hygiene to overcome what they termed excessive lasciviousness.

7. John Updike expressed this opinion in an interview conducted by the author of this article, "A Relaxed Conversation with John Updike”, Atlantis, 1996.

8. Henry A. Bright, a British acquaintance of Hawthorne's, in a letter to a friend attributed these words to Ralph Waldo Emerson. 
Hawthorne's ambiguity towards his first born, Una, and his initial reluctance to accept the role of a father has been traced to his disproportionate fondness for little girls and to his ill-hidden desire to be regarded as a child himself. Married to a childwoman, wishing forever to be in the company of little girls, and perceiving himself as a child, it was to be expected that Hawthorne would be reluctant to accept the arrival of his children which altered his infantile status and defined him as a father. In April 1844 he wrote: "I do not think that I am the more conscious of the baby, by standing aloof from her. She has not yet sufficiently realised herself in my soul" (16:29). In December 1844, when Una was already eight months old, he still had trouble in accepting her birth. He wrote to Sophia: "I long to see our little Una; but she is not yet a vital portion of my being" (16: 68). These feelings are associated to his belief, as presented in Doctor Grimshawe's Secret, that loving one's own children does not have to come naturally. He often remarked that he did not have any natural partiality for his own children, and that he could love other people's children better than his own, provided they were more deserving.

Accepting his male offspring was even harder for Hawthorne. In 1844 he had written to Bridge: "I think I prefer a daughter to a son" (16: 25), and he still held this opinion after fathering Julian in 1846; Sophia, unaware of anything obscure or pathologic in her husband's disregard for boys, half teasingly writes to Bridge six months after the birth of Julian: "His father [Julian's] declares he does not care anything about him because he is a boy, and so I am obliged to love him twice as much as I otherwise should" (qtd. in Bridge 187). On March 15, 1847 he still had not fully accepted his son when he wrote to Sophia: "I love thee infinitely, and need thee constantly. I long to hear Una's voice. I find that I even love Bundlebreech!!!” (16: 201). ${ }^{9}$ His partiality continued and is documented by recurrent remarks, as in the different responses and excuses he made on the occasion of his children's visits to Mr. and Mrs. Fields. Of his daughter he writes: "I hope you like her. We do" (18: 523). Of his son he wrote: "I hope Julian's visit has not bored you intolerably. It is certainly a relief to us to get rid of him occasionally; he is too big for a small house. Don't tell him so, however" (18: 508). As late as 1855 Hawthorne was still thinking that "all boys are the awkwardest and unbeautifullest creatures whom God has made" (17: 419-420). The abundance of comments along these lines fuels conjectures about the origins and consequences of Hawthorne's strong predilection for female children. However, Vernon Loggings does not distinguish between girls and boys when he pronounces that simply being a father crucially influenced his literature. While discussing Ebe Hawthorne's concern that marriage would interfere with the development of her brother as a writer, Loggings observes: "she [Ebe] should have known that he would never get control of his full powers as an artist until he had children of his own" (259-260).

\footnotetext{
9. Bundlebreech was the nickname Hawthorne used for his son Julian.
} 
Indeed Carroll's personal interest for little girls was far more conspicuous than Hawthorne's, and it is indubitable that little girls prompted and inspired his fictional writings. Nevertheless, it is Hawthorne, much more than Carroll, who projects this fascination onto his fiction. In literature he constantly engages on the topic of the intimate relationship and intense rapport between mature male characters and innocent unstained female children. His very first novel, Fanshawe, had already presented in 1828 a version of this pattern. Ellen is a child-like young girl whose close subordinate relationship with an older male, her surrogate father Doctor Melmoth, invites analysis. Melmoth's wife is, in some ways, displaced by Ellen, as the narrator's words seem to indicate:

From the time that Ellen entered Dr. Melmoth's habitation, the sunny days seemed brighter, and the cloudy ones less gloomy, than he had ever before known them. He naturally delighted in children; and Ellen, though her years approached to womanhood, had yet much of the gayety and simple happiness, because the innocence, of a child.- the rich recreation that he promised himself for hours of literary toil. ${ }^{10}$

Significantly, Ellen is also the only human being admitted within the walls of the "secret retreat of his study" (20).

Then there is the relationship between Annie and the narrator in the above mentioned "Little Annie's Ramble". The story line is meagre, and tells the audience about a seemingly innocent ramble that a five-year-old girl and the male adult narrator take around a village. At first sight this simple plot line seems to contain little that is hidden under the surface. However, a closer analysis shows that some darker interpretations are possible. Most of all it is significant that when their ramble is interrupted by the girl's mother calling her back home her companion exclaims: "forget not to thank heaven, my Annie, that after wandering a little way into the world, you may return at the first summons, with an untainted and unwary heart" (155). The choice of words allows a different and disturbing interpretation of the ramble.

Similar little girls in ambiguous dangers will appear intermittently. In 1841 Hawthorne published The Whole History of Grandfather's Chair. In this collection as well, a male adult paternal figure enjoys a remarkable rapport with yet another of those innocent little girls. The narrator justifies this harmony between these two unequal characters by explaining that, though they are different, "the heart of both could be gladdened with the same joys" (69). Grandfather, who incarnates the authorial persona, is thus overtly and coherently identified with childhood. It is also meaningful that among the four children who play a significant part in the story frame, grandfather displays a distinct partiality for Alice, who is just about Annie's age. The audience is informed that grandfather's heart "leaped with joy whenever little Alice

10. Nathaniel Hawthorne, Fanshawe, p. 20. All subsequent references to Fanshawe correspond to the Houghton \& Mifflin edition listed in the bibliography. 
came fluttering like a butterfly into the room." (10). Alice is forced by a male adult to shed the symbolic tears of growth. In his zeal grandfather has exposed her to evil, and he is as fully aware of the role he is playing as Annie's companion was. He unregretfully clarifies to the older children, after he has told the story meant to initiate little Alice: "Her heavenly nature has now received its first impressions of earthly sin and violence" (204).

In some of the stories of Tanglewood Tales, a collection of Myths adapted for children, Hawthorne alters the story to suit his interest for little girls. For instance, in "The Pomegranate Seeds", the classical myth concerning the seduction of Proserpina by Pluto, this young woman is metamorphosed into a beautiful little girl, one of Hawthorne's radiant female children; meanwhile Pluto is portrayed as a lonely man who, in spite of his surface fierceness, is just searching for love and companionship which he finds in little Proserpina. This beautiful but foolish little girl experiences an initiation which she was in need of, since it was only as a result of her "dangerous" naiveté that she had been previously abducted by Pluto. Once again we have the usual pattern: adult male exposing prepubescent girl to an experience which is to constitute her initiation. Proserpina, like Dante, descends into the darkness and fire of hell only to emerge triumphantly the following spring. On her emergence she will presumably be the possessor of sufficient knowledge of the world's evils to avoid further abductions. Contrary to Wordsworth, who connected experience to death, Hawthorne, at this point the father of two children, believes initiation is essential for their survival. Pluto's expectations concerning children are not very different from Dodgson's when the latter writes: "I am very fond of children, and their society is a great refreshment, sometimes, to an old bachelor" (Cohen 2: 546-547). And when Dodgson says children he means female children.

Moreover Hawthorne was not the only nineteenth-century American writer to dramatise little girls in close association to adult males. Among the superabundance of saintly children of both sexes in the second half of nineteenth-century American fiction a number of fictional little girls are associated to father figures. These fathers or father surrogates are wont to be handsome men with an intense devotion for their daughters. In the above mentioned Elsie Dinsmore Elsie's relationship with her father, according to Anne Scott MacLeod, verges on the erotic (153). In Susan Bogart Warner's best seller The Wide, Wide World, in spite of its emphasis on religion, there is a repressed eroticism between Ellen, who is ten at the start of the story, and her surrogate father twenty-three-year old John. It is clear that though Carroll is the nineteenth-century writer whom we most readily associate with little girls, there were many others fascinated by immature femininity; and specifically Hawthorne is one whose fictional universe is fraught with them.

However we do not wish to imply that there ever existed overt, or indeed even conscious, erotic feelings between Hawthorne and any of his little girls, either fictional or real, but it is undeniable that the ambiguous dangers to which they are 
frequently exposed hint at something dark. It must be remembered that in nineteenthcentury America sex had to be avoided or disguised. However, though sex was almost banished from the surface of stories about children, Anne Tropp Trensky aptly observes that "it frequently sneaks back into the stories-albeit unconsciously-often in incestuous forms" (389). David Reynolds has also remarked that the American social and literary scene at Hawthorne's writing period was deeply riddled with sexual tensions and that perversions and sex with children was not unheard of. Taking into consideration that Hawthorne was an expert in hiding the truth and keeping sensitive things out of his writing, and that it was one of his fortes to write tales of hidden corruption, it seems justifiable to conjecture that the danger to which his little girls are frequently exposed is a sexual one. If this hypothesis be true, Hawthorne's yearnings, of whatever nature, were sublimated, resulting in works of fiction which are haunted by the desires which inspired them. It is the office of contextualist approaches of literary criticism, specifically biographical or psychological, to discover exactly how this author's ill-defined feelings towards little girls influenced his fiction.

\section{Works Cited}

Arvin, Newton ed. The Heart of Hawthorne's Journals. Boston: Houghton \& Mifflin Company, 1929.

Bridge, Horatio. Personal Recollections of Nathaniel Hawthorne. New York: Haskell House Publishers, 1893.

Cohen, Morton. ed. The Letters of Lewis Carroll. New York: Cambridge UP, 1979.

Finley, Martha. Elsie Dinsmore. New York: Dodd, Mead, 1893.

Hawthorne, Julian. Hawthorne and His Wife. 2 vols. Boston: Houghton Mifflin Company, 1884.

Hawthorne, Manning. "Parental and Family Influences on Hawthorne", Essex Institute Historical Collection 76 (January, 1940): 1-13.

Hawthorne, Nathaniel. The Centenary Edition of the Works of Nathaniel Hawthorne. Ed. William Charvat et. al. 23 vols. to date. Columbus: Ohio State UP, 1962-.

Fanshawe. Boston: Houghton Mifflin Company, 1872.

“Little Annie's Ramble, Twice-Told Tales. Boston: Houghton Mifflin Company, 1872.

The Whole History of Grandfather's Chair. Boston: Houghton Mifflin Company, 1872.

Herbert, T. Walter. Dearest Beloved: The Hawthornes and the Making of the Middle-Class Family. Berkerley: University of California Press, 1992. "Divine Childhood in the Hawthorne Household", Essex Institute Historical Collection 125 (January, 1989): 45-54. 
MacLeod, Scott Anne. A Moral Tale: Children's Fiction and American Culture, 1820-1860. Hamden, CT: Archon Books, 1975.

Pearson, Norman Holmes. "Elizabeth Peabody on Hawthorne", Essex Institute Historical Collections. 114 (July 1958): 134-46.

REYNOLDS, S. DAVID. Beneath the American Renaissance: The Subversive Imagination in the Age of Emerson and Melville. Cambridge: Harvard UP, 1989.

STEWART, RANDALl. "Recollections of Hawthorne by His Sister Elizabeth", American Literature 37 (July, 1945): 53-65.

Trensky, T. Anne. "The Saintly Child in Nineteenth-Century American Fiction", Studies in Short Fiction 27 (4, 1990): 509-516. 